\title{
Musa Michelle Mattiuzzi: Radical Wanderings, Gestures of Terror and Fugitivity in Flesh ${ }^{*}$
}

\section{Fabiana Lopes**}

\begin{abstract}
In this essay, I provide a brief overview of Musa Michelle Mattiuzzi's artistic output (works created between 2012 and 2018), focusing on some of her performances, ephemeral live actions, and writings. At the same time, I read Mattiuzzi's practice in dialogue with a few other black woman artists from Brazil, thus offering one provisional and short mapping of the current output from black Brazilian artists. Through this mapping, I attempt to provide an expanded understanding of contemporary artistic production in Brazil and offer some insights on particular interventions to the field that have been made by black Brazilian artists. I also argue that, through what I am naming radical wanderings, Mattiuzzi stretches and deepens the tension created by her body and presence (and by art) in the public sphere, thus making a radical expansion on the discussion proposed by some of her contemporaries about black womanhood in Brazil. Moreover, I argue that Mattiuzzi's aesthetic procedures (re)present a theoretical feminist intervention.
\end{abstract}

Keywords: Michelle Mattiuzzi, Performance, Black Performance, Contemporary Art, Contemporary Art from Brazil, Black Brazilian Artists, Black Feminism.

* Received December 31 2019, accepted June 252020.

** PhD Candidate at New York Unviersity, New York, USA. fabiana@fabianalopes.com / https://orcid.org/0000-0002-8984-0975 


\section{Musa Michelle Mattiuzzi:}

perambulações radicais, gestos de terror e fugitividade em carne

\section{Resumo}

Nesse artigo, apresento um breve overview da prática artística de Michelle Mattiuzzi (trabalhos realizados entre 2012 e 2018), focando em algumas de suas performances, ações efêmeras $e$ textos. Ao mesmo tempo, faço uma leitura da prática de Mattiuzzi em diálogo com algumas artistas brasileiras, oferecendo, assim, um mapeamento curto e provisório da produção atual de artistas negras e negros no Brasil. Através desse mapeamento, tento oferecer um entendimento expandido da produção de arte contemporânea no Brasil, bem como alguns insights sobre intervenções específicas feitas no campo por artistas negras $e$ negros. Também argumento que, através do que chamo radical wanderings (perambulações radicais), Mattiuzzi esgarça $e$ aprofunda a tensão criada por seus corpo e presença (e pela arte) na esfera pública fazendo, portanto, uma expansão radical na discussão proposta por algumas de suas contemporâneas sobre a experiência da mulher negra no Brasil. Argumento ainda que os procedimentos estéticos de Mattiuzzi (re)presentam uma intervenção teórico feminista.

Palavras-chave: Michelle Mattiuzzi, Performance, Performance Negra, Arte Contemporânea, Arte Contemporânea no Brasil, Artistas Negros Brasileiros, Feminismo Negro. 
I'm on the run. For a black person, running is part of their

life story in resistance: the Diaspora... ${ }^{1}$

(Mattiuzzi, 2019)

[B]lack performance... does not disappear the problem; it is the problem and will not disappear. It is, moreover, the problem diffusion...

(Moten, 2017)

\section{MICHELLE MATTIUZZI}

aquela uma mulher tão preta

quanto eu e eu ainda mais

preto perto dela ela quase azul

eu já quase ela uma e outro

sob a noite retinta

do baixo belô ela e eu meio

sem forças para o abraço

e cada vez mais fortes

por causa do abraço

ali em plena rua todo mundo

olhando e ninguém nos vendo

ela tão preta e eu tão ela

dois corpos vivos de ébano

náufragos no mesmo

mar de lágrimas negras

que ela chorava

(dentro-para sempre-de mim) sem fim.

\section{MICHELLE MATTIUZZI}

That one woman so dark

like I am and I even

darker near her almost blue

I already quasi her one and other

under the overly dark night

at baixo belô she and I almost

${ }^{1}$ This is part of a brief statement by the artist published in a Contemporary And magazine editorial in 2019. 


\author{
without strength to hug \\ there at the street everyone \\ looking and no one noticing us \\ she so dark and I so her \\ two living ebony bodies \\ castaway in the same \\ sea of black tears \\ that she was crying \\ (inside-always-in me) endlessly (Aleixo, 2019).
}

When Salvador based artist Musa Michelle Mattiuzzi (b. 1983) first enacted Merci beaucoup blanco!/ Thank you Very Much Whitey! (2012), she was responding to a couple of provocations, including artist Paulo Nazareth's work "Qué ficar bunitu?" (D'ya Wanna Be Beautiful?). Handed out by Nazareth in person, "Qué ficar bunitu?" (Image 1) is a pamphlet resembling an ad for an imaginary beauty salon DE BESTI BIRIFUU, a play in Portuguese language to the English sentence "the best beautiful." The pamphlet is illustrated on the top with the portrait of a black male (likely an enslaved person) paired with a text describing the services offered by the house and its address. The text reads:

We can perm your hair, bleach your skin, narrow your nose, cut your ears, color your eyes, shrink your breast, narrow your buttocks, wax your underarms, cut out your nails, narrow your lips, sand your feet, change your name, We teach you English, perfume you, we take your picture, we find you a sponsor, we give you a scholarship, we grant you a visa, we send you abroad, we blot out your memory, we make you beautiful. 
Image 1: Paulo Nazareth, Quer ficar bunito?, flyer

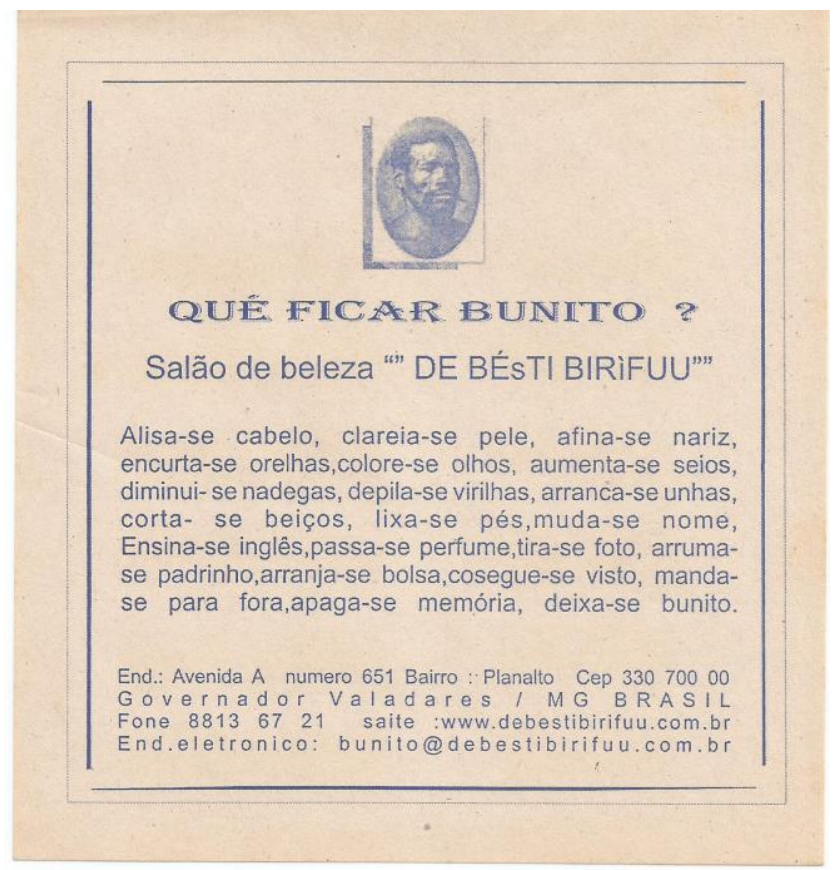

Source: Courtesy of the artist.

In this short and dense piece, Nazareth engages in a discussion that conflates social status, class position and racial issues, a pervasive strategy throughout his artistic practice. Mattiuzzi responded to Nazareth's challenge with her own body by creating a visual interpretation of the piece. Wearing nothing but a pair of red high heel pumps, she ritualistically pours white paint over herself until her entire body is covered. In this painting process, Mattiuzzi engages in sensual gestures, suggestions and provocations while gazing at the viewer mischievously: she slowly rubs her breasts and her buttocks, she paints her vagina and poses provocatively, alternating from standing to sitting on a revolving stool, playfully turning to the right and left, opening her legs, smiling, giggling, staring at viewers. Drenched with white paint, 
Mattiuzzi crouches down and, in slow movements, extracts a long chain of fake pearls from her inside vagina. Another round of playful acts takes place, now with the pearl chain. Coming full circle, she finishes her performance reading aloud Nazareth's Qué ficar bunitu? (Images 2, 3 and 4).

Image 2: Michelle Mattiuzzi, Merci beaucoup blanco! (2012), performance, Salvador - BA.

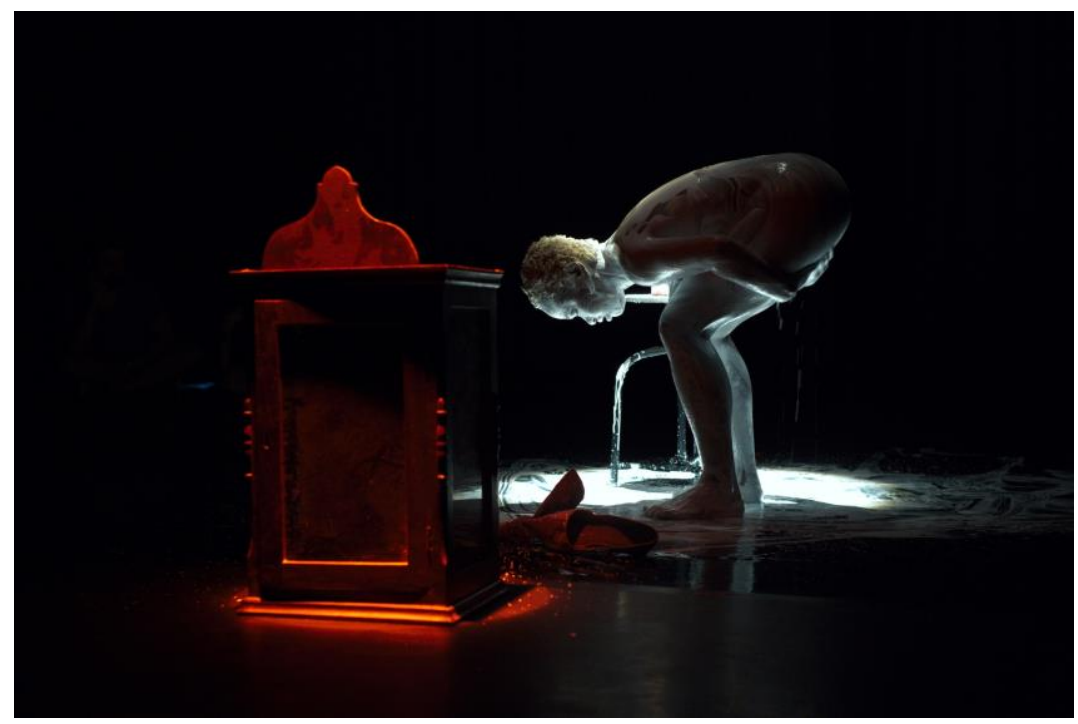

Photograph: Hirosuke Kitamura. 
Image 3: Michelle Mattiuzzi, Merci beaucoup blanco! (2012), performance, Salvador - BA.

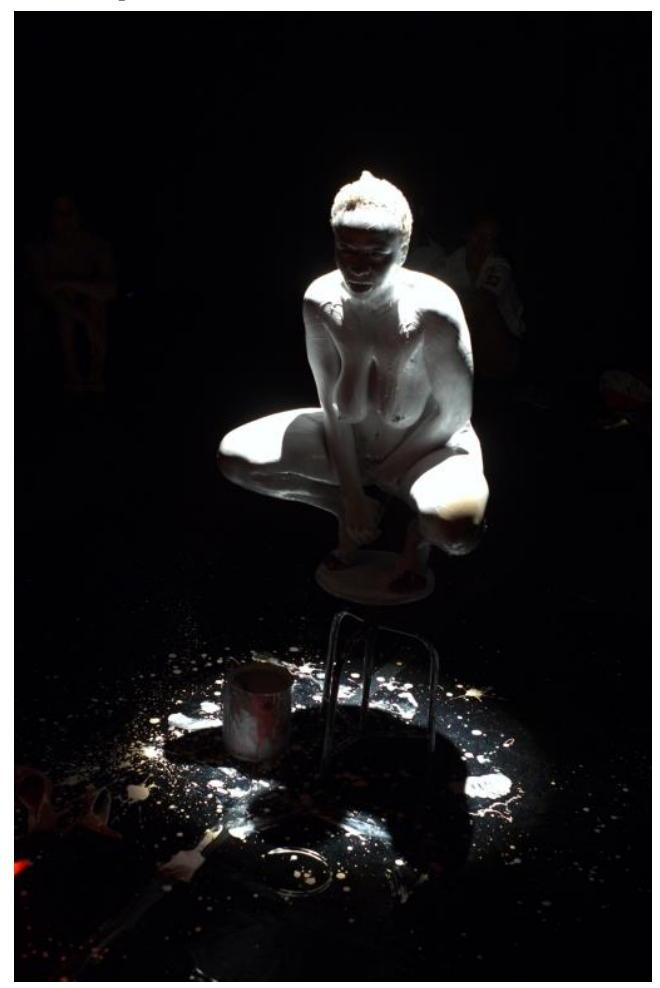

Photograph: Hirosuke Kitamura. 
Image 4: Michelle Mattiuzzi, Merci beaucoup blanco! (2012), performance, Salvador - BA.

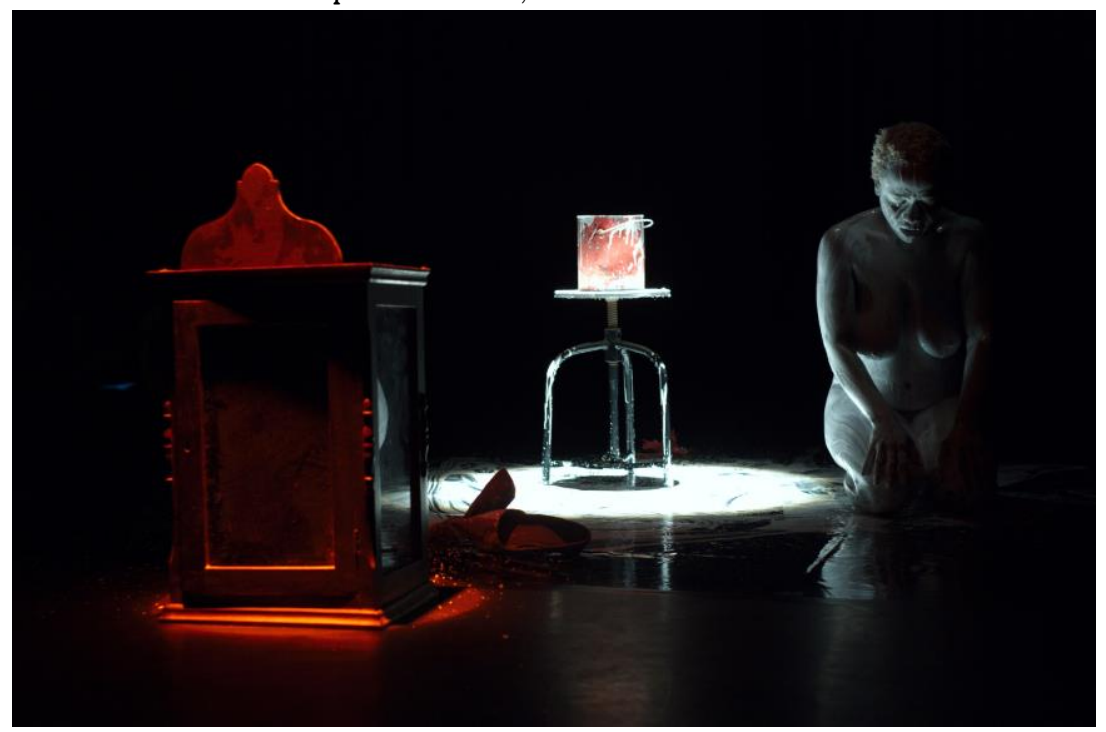

Photograph: Hirosuke Kitamura.

"Have you met Michelle Mattiuzzi yet?" "Do you know her work?" "You need to see Mattiuzzi's work." These are some of the questions and comments I would often encounter while doing studio visits or in conversations with artists in São Paulo about the local art scene during a field research in 2014-2015. For a while, despite these flood of inquiries and comments, I couldn't easily find either Mattiuzzi nor her work. Mattiuzzi has been performing for roughly 10 years. Her work, however, remained for a while a hard-to-capture practice, usually experienced within the public sphere and confounded with the everyday. I wonder if the ephemeral nature of Mattiuzzi's actions, for the most part not available through documentation, may be one of the reasons why her work hasn't always been explored through critical engagements.

I want to take Mattiuzzi's ephemeral actions seriously and think of her practice in dialogue with the practices of a few other 
black woman artists in Brazil. I argue that taking the time to study these connections provides an expanded understanding of contemporary artistic production in Brazil and gives some insights of particular interventions to the field that have been made by black artists in particular. Moreover, I argue that Mattiuzzi makes a radical expansion on the discussion proposed by some of her contemporaries about black womanhood in Brazil, and offer, through her work, an aesthetic iteration of black feminist theories. Through what I am naming "radical wanderings," Mattiuzzi stretches and deepens the tension created by her body and presence (and by art) in the public sphere. I will also attempt to trace the hints Mattiuzzi provides about her moves in her written works, tracing, whenever possible, its connections with black feminist narratives.

Performance art has been taking a prominent space within the contemporary production of black artists in Brazil lately, and their works have been featured in exhibitions such as Metrópole: Experiência Paulistana, at Pina_Estação (2017), curated by Tadeu Chiarelli, Agora Somos Todxs Negrxs? at Galpão Video Brasil (2017), curated by Daniel Lima and Negros Indícios, at Caixa Cultural (2017), curated by Roberto Conduru (this one dedicated exclusively to performance and with an important exhibition catalogue), PretAtitude at Rede Sesc (2018-2019), curated by Claudinei Roberto da Silva-the four of them in São Paulo, and Vozes do Silêncio, at Universidade Federal Goiás, Goiania (2017), curated by Paulo Henrique Silva. This turn to performance had been addressed by Bispo and Lopes in "Presença: performance negra e o corpo politico" (Bispo and Lopes, 2015), a rare kind of text, in that moment and context, dedicated to works by black Brazilian artists. It has also been addressed by Lopes in her essay "Black Performance in Brazil: Hidden Stories and the Rough Vibrancy of Now" (Lopes, 2019).

Another recurring event within contemporary art field in Brazil has been that of black women artists turning to discussions about the black female subjectivity and/or the condition of the black woman within Brazilian social context. São Paulo based 
artist Rosana Paulino (b. 1967) is often credited as a pioneer in explicitly taking up such issue. Using a recurring practice that she names as "suturing," as oppose to sewing, Paulino strategically discloses unaddressed social issues providing an expanded understanding of her cultural context. Through her suturing practice, among other formal strategies, she engages on an investigation that revisits the history of the transatlantic slavery trade and it's connection with race science, natural history and their unfolding implications in contemporary Brazil. Paulino does so by taking the perspective of the black woman as vantage point. I use the term "pioneer" with caution since my intention here is not to place Paulino's work as point of origin. Conversely, I take her work as a point of contact. I want to stretch it as both a place of encounter and point of departure. This placement also serves as a pausing gesture, a brief moment to hold space in honor to other black Brazilian women artists who have engaged in similar project but remain unknown and unacknowledged.

With a less explicit take on addressing issues related to the condition of the black woman, Lidia Lisbôa (b. 1970) creates, through crocheting strips of discarded tulle and other textile material, objects whose titles (or forms) are, at times, related to the female body, as is the case of the series Tetas que deram de mamar ao mundo/ Teats That Breast Fed The World (2015-2020), or the series Cicatrizes/Wounds (2012-2010), Casulo/Cocoon (20142020) (Lisbôa relates Cocoon to the uterus, and wounds as those of the woman body). Lisbôa's practice, however, presents an intriguing combination between textile objects and performance. This combination, or split, makes it possible to consider her in a kind of transverse cartography with Paulino, Lisbôa and a younger generation of black women artists who seem to deepen investigations centered on black women perspectives, particularly on gender and race, while taking up performance art as their central medium. ${ }^{2}$

\footnotetext{
${ }^{2}$ I am using the term "transverse" because Lisboa's work has tangent connection with artists Rosana Paulino and Sonia Gomes in its relation to working with textiles and to the practice of sewing (suturing to Paulino). However, her work
} 
A list of artists and works immediately come to mind, and it includes Renata Felinto (b. 1978), with Danço na terra em que pisol I Dance On The Ground On Which I Tread (2014), and White Face Blond Hair (2012); Janaina Barros (b. 1979), with Eu que sou exótica gostaria de recortar um pedaço do céu para fazer um vestido, ou jogo de probabilidades/Since I Am An Exotic Woman, I Would Like To Cut a Piece of The Sky To Make A Dress, Or Game of Probabilities (2014) and A Paixão de ClaudialClaudia's Passion (2015), or even Psicanálise do cafuné: cantiga de mulata/Cafunés Psychoanalysis: Mulata's Song (2017); Charlene Bicalho (b. 1982), with Mergulhos em si/Diving In Oneself (2018) or Onde você ancora seus silencios/Where do you anchor your silences (2017); Priscila Rezende (b. 1985), with BombrillBrillo (2010); Val de Souza (b. 1985), with Can You See It? (2016); Natalia Marques-Emaye (b.1986), with Melaço (2015); Millena Lizia (1986), with Faço faxina/I Do Cleaning (2016-2018); and Juliana dos Santos (b.1987), with Que Pente? Which Comb? (2014) and Tempestade/Storm (2013), to name a few.

Providing a list of artists and works, even if as short as the one above, while discussing the work of black artists in Brazil, in general, and black woman artists, in particular, has become both a strategic and political move. Since these artists and their practices have been often time overlooked, dismissed, or portrayed as if existing in isolation, such lists give room to a cartographic exercise, offering a brief (and important) map of artistic ecosystems. They also put pressure on the interpretative epistemologies available. How do we attend to the violence of those erasures? How can we approach this ecosystem of artistic practices in a generative way? How the practices within this set can be articulated in relation to one another? What are the points of similarities and dissimilarities among them? These are questions that may inform future scholarships and provide more expansive insights about the contemporary art scene in Brazil.

also is steeped in performance, connecting her with the upcoming generation of black visual (woman) artists working with performance. 
Similar to Mattiuzzi's practice, these artists take the body as site of investigation. To them, the body is both artistic medium and the means through which to understand one's own position in the world, while negotiating and reclaiming territories. By taking the investigation on their bodies, these artists seem to offer alternative theoretical entry points to black feminist considerations in a context where such considerations are not welcome or are foreclosed altogether. I argue that these black female artists mobilize their (abject) object position into an aesthetic practice (of resistance). Their actions, in excess to their surplus condition, spill over as (black) (avant-garde) (philosophical) performances.

In Musa Michelle Mattiuzzi, however, these considerations seem to be stretched to a breaking point since the artist intensifies the tension related to her body/presence in the world. In discussing this work in a recorded interview at Vasli Souza Gallery (Malmo, 2013), Mattiuzzi states that upon returning to São Paulo from a trip abroad, she became more aware of how her body is socially perceived. "I return to my country," she says, "and have to confront all the stereotypes related to this black body" (Mattiuzzi, 2013).

While addressing the issue of stereotypes related to black woman in her essay "Genero e raça na sociedade brasileria" [Gender and Race in Brazilian Society], feminist scholar Sueli Carneiro (Carneiro, 2018) attributes to fiction literature the role of systematically reinforcing the markers assigned to woman and to the black woman, in particular, within Brazilian society. "The black woman," Carneiro states, "is depicted as exotic, sensual, sexually provocative...characterizations which pair her with an animal like form [as if] destined exclusively to sexual pleasure." ${ }^{3}$ Hip-Hop singer Tassia Reis would say (sing) it this way

Vocês me disseram que não poderiam me contratar Porque minha aparência divergia do padrão

${ }^{3}$ In the original in Portuguese, "a mulher negra será retratada como exótica, sensual, provocativa... tais características chegam a aproximá-la de uma forma animalesca, destinada exclusivamente ao prazer sexual". 
(Que padrão?)

Que eu era até legal

Mas meu cabelo era crespo demais (crespo demais)

Talvez alisar seria uma solução

Não, não, não

Não, não, não, não

Que eu tinha que me enxergar

Porque toda moça preta demais

Preta demais sabe que o seu destino é limpar chão (Chão!)

(...)

A gente pode se pegar, mas, ó

Você cria expectativa demais

(Cria demais)

Além do mais, eu amo a Becky do cabelo bom

(...)

You've told me that you would not hire me

Since my appearance is different from the standard one.

(Which standard?)

That I was even cool

But that my hair was way too nappy (way too nappy)

And maybe perm it would be a good solution

No, no, no

No, no, no, no

That I should wake up

Since any woman that is too much black

Too much black knows her destiny is to clean the floor

(The floor!)

(...)

We can even make out, but look

You have too much your hopes

(Too much hopes)

Besides, I love Becky the one with good hair.

(...)(Reis, 2019)

North American feminist theorist Hortense Spillers, starts her 1987 seminal essay "Mama's Baby, Papa's Maybe: An American Grammar Book" calling out names (or marks) that imply some of 
these stereotypes: "'Peaches' and 'Brown Sugar', 'Sapphire' and 'Earth Mother' 'Aunty', 'Granny', God's 'Holy Fool', a 'Miss Ebony First', or 'Black Woman at the Podium'" (Spillers, 1987). To Spillers, these names-marks represent a "locus of confounded identities, a meeting ground of investments and privations in" what she calls "the national treasury of rhetorical wealth" (Spillers, 1987). I read these two important black feminist philosophers (one from Brazil and other from the U.S.) in dialogue in an attempt to expand our understanding of Mattiuzzi's assessment of the perceptions about black womanhood in contemporary moment while I am also hopping that the theoretical articulations offered by Mattiuzzi and Reis will expand our philosophical reach.

It is in that context of (re)assessing the meaning evoked by her physical presence that Mattiuzzi encounters Nazareth's work. Her engagement with the piece, she maintains, is both of "identification and non-identification," to use her words. It is a relation of proximity and distance as the artist reads the description, or list of actions, offered in Qué ficar bunitu? - a trans-formation of a sort, a transition into whiteness. On the other hand, the reading also provides an imaged statement of what her body is not. Mattiuzzi takes Nazareth's text as a "potent material," a source to guide her in developing the (black) thing that is not into performance, a thing that will likely fit to, in her own words, "the white hegemonic system [that] annihilate all other possibilities of body" (Mattiuzzi, 2013). It was Nazareth's work at the moment of Mattiuzzi's return that prompted the performance piece. And the questions I want to raise here are: why Mattiuzzi realized her condition as a fractured subject only after returning from a trip abroad? What is it about leaving, and returning to, one's domestic geopolitical location that makes one to perceive things differently, including oneself? How can we theorize the return? ${ }^{4}$

\footnotetext{
${ }^{4}$ Mattiuzzi states in an interview that she had faced events of racism earlier in her life. From which we can infer that her double awareness, her experience of seeing herself through the eyes of others had happened before. I argue, however, that after her first trip abroad she had a renewed understanding of the social meaning and implications of these events.
} 
Nazareth's ad resembles the initial advertisements and runaway ads made by slave owners in the colonial period, either offering slaves for sale or looking for fugitives, using a format comprised by a descriptive text. Nazareth reproduces the format picture-text. However, in this case, the description is replaced by a list of actions which, once taken, would transform one's physical features. The suggestion is that a change in one's physical characteristics may promise a change in her/his social status and condition.

In her text Scenes of Subjection: Terror, Slavery and SelfMaking in Nineteenth-Century America, cultural historian Saidiya Hartman discusses the "persistent production of blackness in the post-emancipation U.S. as abject, threatening, servile, dangerous, dependent, irrational and infectious," the production of "blackness as the work of object status," and of "[W]hiteness as the norm of humanity" (Hartman, 1999). Such production of whiteness as normative reference and blackness as abject object can also be verified in the Americas in general and specifically in Brazil. Addressing, for example, the characteristics of what she calls "the aesthetic of whitening ideology" in Brazil, Lélia Gonzalez asserts that according to this ideology standards, to be considered beautiful, the black woman is expected to have "fine features," "good" hair (straightened or disguised under a wig), or even to (re)produce the erotic/exotic type" (Gonzalez, 2018). Thus to "make you beautiful," as Nazareth's ad promises, means to provide one with a new (normal white) body. Mattiuzzi, however, challenges the idea of the ad. She stands as the (abject) body in constant view, as the (abject) body on display.

In Merci beaucoup, Mattiuzzi does not replicate the actions she reads in Nazareth's work. Conversely, she creates a metaphor that encapsulates their meaning while providing a critical reading of them. The pouring of white paint partially erases, or attempts to erase the body she inhabits. The act symbolically covers blackness with whiteness. In a multilayered turn, Mattiuzzi alternates between rejecting, and playing with the conflicting markers associated to her body, this abject object, this object of desire and, as Spillers puts it, 
this "source of irresistible, destructive sensuality" (Spillers, 1987). ${ }^{5}$ Thus Mattiuzzi thrusts her nonconforming body onto the hegemonic frames of beauty, disrupting the very grammar of beauty and making, as a result, herself less legible and comprehensible.

Scholar Tanía Kateri Hernandéz states that, despite the large contingent of African people forced into Brazil during the course of three centuries of its slave trade, Brazil stands out as a case study amongst Latin American countries for its extended "network of racial restrictions to regulate race after the abolition of slavery." One common regulatory practice was branqueamento (whitening), defined by Hernandéz as "an ideology and a set of practices to whitening the Brazilian population and presumably modernizing the nation" (Hernandez, 2013:47). Branqueamento, as both ideology and a set of practices, is a complex concept that has been extensively discussed by prominent Brazilian scholars such as Aparecida Bento, Florestan Fernandes, Antonio Sergio Guimarães, Lélia Gonzalez, Carlos Hasenbalg, Andreas Hofbauer, Abdias do Nascimento, and Lilia Schwarcz. My concern here, however, is with how the issue has been taken up in contemporary art. Merci beaucoup is one in a set of (black) performances that have recently emerged in Brazil, animated by this social-political context and thus have been making an intervention in this discussion. This set of performances, I argue, can be historically situated and understood as part of an "existing political mobilization" (Martin, 1998:206). A few examples are Juliana dos Santos' (b. 1987) Tempestade/Storm (2013), and Antonio Obá's (b.

${ }^{5}$ While theorizing on issues of captivity and intimacy, Spillers writes: "This profound intimacy of interlocking detail is disrupted, however, by externally imposed meanings and uses: 1) the captive body becomes the source of an irresistible, destructive sensuality; 2) at the same time-in stunning contradictionthe captive body reduces to a thing, becoming being for the captor; 3) in this absence from a subject position, the capture sexualities provide a physical and biological expression of "otherness"; 4) as a category of "otherness," the captive body translates into a potential for pornotroping and embodies sheer physical powerlessness that slides into a more general "powerlessness," resonating through various centers of human and social meaning (Spillers, 1987:67). 
1983) Atos da Transfiguração-receita de como fazer um santo/Acts of Transfiguration-Recipe of How To Make a Saint (2015), Abiniel João Nascimento's (b. 1996) Corpo negro, cabeça branca/Black body, white head (2018), Moises Patricio's (b. 1984) series Aceita?/Do You Accept it? (2014-ongoing). In Tempestade, Santos is photographed with her body covered with white paint and clothes, including a white head wrap piece, while trying to camouflaging on a white sofa placed against an all-white backdrop (Image 05); in Atos da Transfiguração, Obá, keeling with his naked body, ritualistically grates the image of a large Catholic saint cast in clay transforming it into dust. Once the long labor of grating is over, he throws the white dust onto his body, still in a ritualistic manner, until he is completely covered in white. Nascimento sits shirtless on a busy public corner of downtown Recife and slowly covers his head with white paint only to try to undo the process with water. In Patricio's series Aceita?, one of the photographs features the image of his (black) right hand open covered with white paint ${ }^{6}$ (Image 6).

These insistent and recurring interventions [performances] of rendering the black body white require that we ask some specific questions. Cedric J. Robinson, in his theorization of the character of the Black Radical Tradition, or of the "ideological, philosophical, and epistemological natures of Black movement [black performance]," offers some useful ones for my discussion: "What events have been most consistently present in Black movement (black performance) phenomenology? Which social processes has it persistently reiterated? From which social processes is it...historically alienated? How does it relate to the political order?... What are its epistemological systems?" According to Robinson, such questions "must" be addressed, now that we are no longer pressed by Western scholarship's paradigm and

\footnotetext{
${ }^{6}$ Aceita?/Do You Accept it? (2014-ongoing) is a series of photographs posted daily on Instagram of Patricio's right hand open in a ceremonial gesture of giving, presenting found objects-bottle lids, pieces of plastic gloves, a colorful fabric, a stick, a flower, a dried bush. The shot stands as a proposition followed by the question "Aceita?Do you accept it?."
} 
analytical categories, by "their uncritical application and the unquestioned presumption" of their universality (Robinson, 2000:167).

Image 5: Juliana dos Santos, Jucelia Bernardo, Marcio Desideri, Tempestade (2009), Still Video Art.

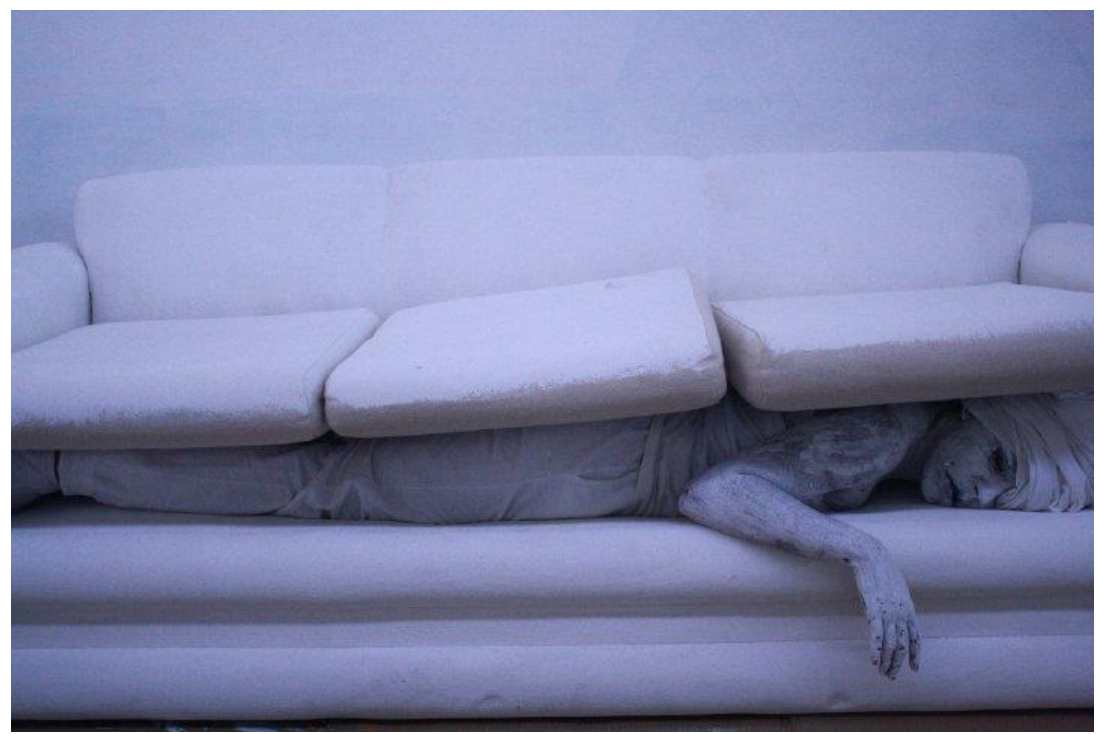

Source: Courtesy of the artist.

These performances also offer, tangentially, a hinge through which we can extend the discussion about painting, on the one hand, and about the monochrome, on the other. How does this discussion look like when trespassed by (para)ontological questions, while holding gestures of disruptions to and escapes from the discourse on (racial) ontology? If, in the (Western) history of art, the monochrome turns the painting into an object, what are the implications of having the body of those who were made themselves abject "objects," those bodies made flesh, as painting or the painting support? How can such consideration amplify our understanding of the current status of the painting practice in Brazil? I am interested in how these questions offer possibilities for 
trespassing the limiting boundaries of Brazilian art history and art criticism narratives. And by limiting boundaries, I mean the lack of knowledge and acknowledgement of the fact that, in the case of afro-Brazilian artistic practice, questions of form come interwoven with reflections about (not)being, which is to say with (para)ontological considerations. With Merci beaucoup, Mattiuzzi offers a chance for wrestling with similar issues. Her artistic practice, however, goes a step further. In a kind of theorizing in the flesh, she presents her body as site, and context, through which to produce theory. Her body-flesh, this object, this container reified through her daily experiences and reduced to a "thing" that is not (it is not beautiful, it is not appropriate, it is not acceptable), she transforms into her discursive (raw) material.

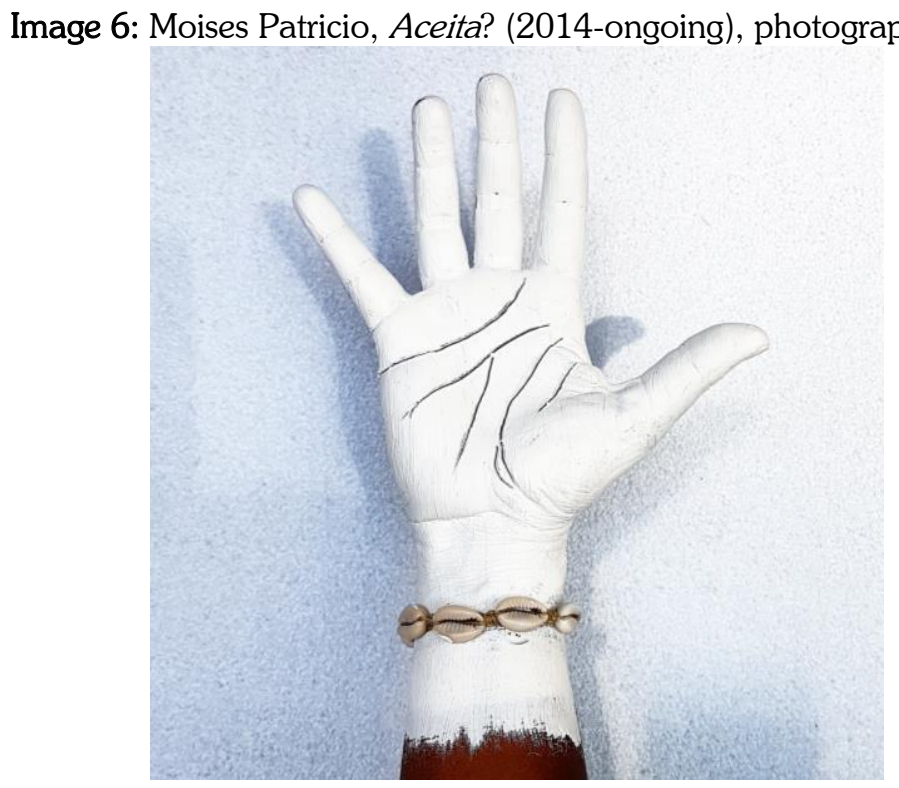

Source: Courtesy of the Artist.

In her conceptualization of "body" and "flesh," Spillers proposes a distinction between both terms. This distinction is, according to Spillers, central to the understanding of the subject- 
positions of the captive and liberated. While the body [relates to] idea of will and self-possession, the flesh stands for a kind of bare living-position, a "zero degree of social conceptualization," usually hidden in discourse (Spillers, 1987). Although the slave trade system inaugurated in the $16^{\text {th }}$ century kidnapped bodies, its crimes-the "lacerations, woundings, fissures, tears, scars, openings, ruptures, lesions, rendings, punctures" were inflicted in the flesh through "the calculated work of iron, whips, chains, knives, the canine patrol, the bullet." Through thinking of "the 'flesh' as primary narrative," Spillers proceeds with a visual interrogation, an investigation of the marks on the flesh to show the link between "racialization and /as bare life," and bare life as a historically transmitted condition, one that is "affixed to certain bodies" (Weheliye, 2014:38). Spillers' intervention is relevant to my reading of Mattiuzzi's practice because it theorizes, as Alexander Weheliye puts it, "some general dimensions of modern subjectivity from the vantage point of black women." It indicates how "dominant symbolic activity, the ruling episteme that releases the dynamics of naming and valuation, remains grounded in the originating metaphors of captivity and mutilation" (Weheliye, 2014:38).

Mattiuzzi's practice seems to (re)activate this lexicon and throw them back to the viewer. Her work unveils an experience on and through the moving "flesh." In one of her texts it reads:

It's been at least three decades that I carry my body throughout the world. I live with [good] mood, bad mood, lack of love, cheerfulness, sadness, happiness, pain, love, passion, colors and many other things that words cannot express (Mattiuzzi, cited in Bispo, 2013:24-28).

Mattiuzzi's body is, at once, her subject and language, content and formal strategy, her only window to the things that words cannot express, things which will, thus, remain unknown. 


\section{Musa Mattiuzzi, Musa das Marmitas}

In one of her collaborations with the Brazilian art collective Opavivará, Mattiuzzi joined the group for the project Arte $e$ Gastronomia (Art and Gastronomy) at the Museu de Arte Moderna, São Paulo (MAM-SP). ${ }^{7}$ The project was part of a series of commissioned collaborative works, between chefs and artists, which took place in the museum. Working with Leo Filho, the invited chef to lead the collaborative work/event coinciding with the opening week of 30a. Bienal de São Paulo in 2012, the art collective Opavivará prepared a range of packed lunch boxes to be shared with passers-by in the area that surrounds the museum at Ibirapuera Park. Mattiuzzi, whose previous collaborations with art collectives granted her the title of Musa (Diva) Mattiuzzi, was invited to join the group as Musa das Marmitas (Lunch-box Diva). ${ }^{8}$ The documentation through photographs shows Mattiuzzi wandering about, dressed in a sexy, red-laced teddy carrying her short pink hair and breasts partially showing. The artist accompanies Filho in collecting herbs in the garden, packing lunch boxes and getting ready to distribute them in the park outside the museum walls. One striking image depicts Mattiuzzi during the packing process in the kitchen. In this photograph the artist is standing, holding one half of a watermelon in her arms, the fruit chiseled inside and intentionally placed over her pubic area. With her body tightened, Mattiuzzi rehearses a scream. Through making a direct reference to the violence historically imposed to a body perceived as excessive-overly sensual, overly sexual - the artist seems also to conflate ideas of pain and play, pleasure and violence. This seemingly non-binary approach to the black body complicates simplistic notions of subjectivity and agency. It also

\footnotetext{
7 The project Arte e Gastronomia (Art and Gastronomy) at MAM-SP consisted of a collaboration between artists and Chefs in artistic/gastronomic events.

8 "Marmita" is how certain food containers are colloquially called in São Paulo region. Although the term refers specifically to the lunch box, it is used as a way to identify individuals who belong to the working class.
} 
provides a tiny hint of, or even a peep to, black life in contemporary (and-never-post-colonial) New World.

One of Mattiuzzi's texts, which is part of what seems to be her ongoing writing project, asserts the following:

I, a black woman, [who is] outside the standards and accepted normative symmetries of this colonial society which affirms the hegemonic Eurocentric forms of representations, I tell the people that I will stay. ${ }^{9}$

Considering Mattiuzzi performance as Musa das Marmitas in relation to her text above raises some questions: If the artist carries a body that is "out of the standards and accepted normative symmetries," a body defined by negation, by what it is not, how can she play the role of Musa (Diva)? What does it do to openly expose a heavily marked body? How can we take Mattiuzzi's open and contradictory play with overbearing sensuality through a body that doesn't match?

In her manifesto/declaration, Mattiuzzi informs that, although her body doesn't match the Eurocentric norms of beauty, she will stay. The assertion "Tell the people that I will stay" is a direct reference to a defining event in Brazil's history, one celebrated as "O dia do Fico," loosely translated into "The Day of 'I will stay [here]'." In 1822 D. Pedro de Alcântara, prince of Brazil assigned by his father D. João VI — who relocated with the royal family back to Portugal after spending 13 years in Brazil-, dismissed judicial orders from Portugal demanding his immediate return. His decision, announced through his famous declaration "If it is for the happiness of the peoples and the general good of the Nation, I am ready. Tell the people that I will stay," ${ }^{10}$ signals a conflict between the assigned government in Brazil and the crown in Portugal, a

\footnotetext{
${ }^{9}$ Translated from the origial in Portuguese "Eu, mulher negra, fora dos padrões e das simetrias aceitas pela normatividade de uma sociedade colonial que afirma as representações da supremacia eurocêntrica, digo ao povo que fico".

${ }^{10}$ The declaration in the original reads'Se é para o bem de todos e felicidade geral da Nação, estou pronto! Digam ao povo que fico."
} 
rupture that would, months later, culminate with Brazil's proclamation of independence. The questions I raise here are: How can we take Mattiuzzi's manifesto-statement, her declaration of intent to stay, in relation to this historically layered context? Is it a play with history? Is it a play with us? What does Mattiuzzi's assertion "I will stay" do? I want to suggest that through her play with historical discourse (and with us), Mattiuzzi shows an open disregard to discourse, to history and to the established norms that dismiss her un-matching self and body. Rather than making claims toward inclusion, she rubs her body on history (and on historical discourse) only to take off on an undirected, erratic route of possibility: that of being a Musa by contradiction. The "I" in "I will stay," the "black woman, [who is] outside the standard," the body that doesn't match the "accepted normative symmetries of this colonial society, " is aware of her surroundings and yet, offering a (tiny) opening to the geographies of her mind, states her intention to stay. In Mattiuzzi, however, the intention is less a reference to a physical location than an indication of her commitment to stay out of the standards and away from [the] accepted, to remain unconforming and errant. Her commitment confirms Fred Moten's assertion that "black art (and black performance)...does not disappear the problem," rather "it is the problem and will not disappear. It is, moreover, the problem diffusion" (Moten, 2017:xii). I keep on hearing Reis singing in the background:

Eu sou demais, eu sou incrível

Eu sou demais e não sou invisível

Eu sou demais

Eu sou incrivel, eu sou demais

Eu sou preta demais

Eu sou preta demais

Eu sou, preta, preta, preta, preta

Preta demais

Eu sou preta, preta demais

Eu sou preta, preta, preta e também sou demais 
[I am awsome, I am incredible

I am amazing and I'm not invisible

I am awsome,

I am incredible, I am awsome,

I'm awsomely black

I'm awsomely black

I am, black, black, black, black

Too black

I am black, awsomely black

I am black, black, black and also awesome] (Reis, 2019).

Image 7: Michelle Mattiuzzi, Experimentando o vermelho em dilúvio (2014), processo 1, performance, Salvador - BA.

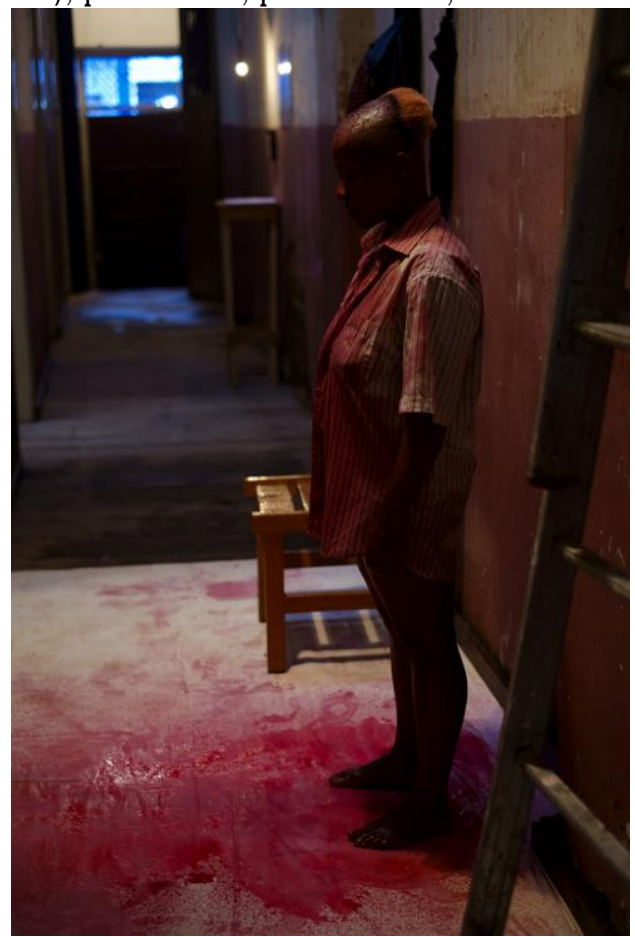

Photograph: Hirosuke Kitamura. 


\section{(Radical) Wandering as Gesture of Terror}

Diffusion, in Mattiuzzi's work, has literal implications. To the problem of her presence, the negr $(\mathrm{A})$ problem, the dark-skinnegr $(\mathrm{A})$ problem, the as-dark-as-the-night-problem, the aquelauma-mulher-tão-preta-quase-azul, yes, that too-dark-almost-bluewoman problem, to the problem of her quasi-monstrous presence, Mattiuzzi responds with a nomadic practice, a practice animated and infused with a measure of the very problem: her presence. I pause here to catch my breath while singing with Brazilian songwriter Bia Ferreira:

Preta, pinta

O mundo com seu tom

Que essa tua negra tinta

Fará brotar a cor nesta cidade, cinza

Que tanto te negou, mas, ô, preta, pinta

Preta, paint

The world with your tone

That this black paint

Will bring forth the color in this gray city

Which have denied you so, but oh preta paint it... (Ferreira, 2018)

In her experimental text "No umbigo do Brasil experimento ABISMO/At Brazil's Belly Button I Experience the ABYSS" (2016), Mattiuzzi states:

When I realized the references that line off the social position of the black woman, I decided to re-inscribe it, claiming a grunt, a cry, a secret. It is a gesture of terror, an act of social performance that has several targets in this sphere of knowledge unfinished and made precarious by white Brazilian meritocratic gaze. Thus there is no way to measure whether the operations I do here are life practices performed within artistic realm. They are a bundle of 
everyday practices of resistance to the daily acts of racism in this imperial colony: Brazil (Mattiuzzi, 2016:1).

With this conceptually packed statement, Mattiuzzi offers us a few clues about her decision to re-inscribe the seemingly tight, limited and limiting "social position of the black woman." However, what does it exactly mean to re-inscribe this position? What is the gesture of terror to which the artist refer? Since the artist doesn't seem to disclose this information, maybe a more generative question would be, what does a grunt, a cry and a secret do?

Mattiuzzi could be seen at the streets, sometimes performing in collaborations with art collectives Opavivara (RJ) and GIA (BA), or in random collective arrangements, in carnival parades, processions or everyday situations, dwelling this terrain of existence in which dispossession, violence and pleasure conflate. Her wandering appears as a project of fugitive movement in hyper terms, as (hyper)visibility in the move. To the tension created by her body-self-presence, to the political, ethical, relational challenge it poses, she adds more tension, more challenge, more diffused presence (Winnicott, 1965, cited in Lewis, 2017). Understanding her presence as terror, Mattiuzzi returns it as a (ungovernable) gesture, as a bundle of everyday practices of resistance to the daily acts of racism in this imperial colony: Brazil. 
Image 8: Michelle Mattiuzzi, Experimentando o vermelho em dilúvio (2016), processo 2,São Paulo - SP.

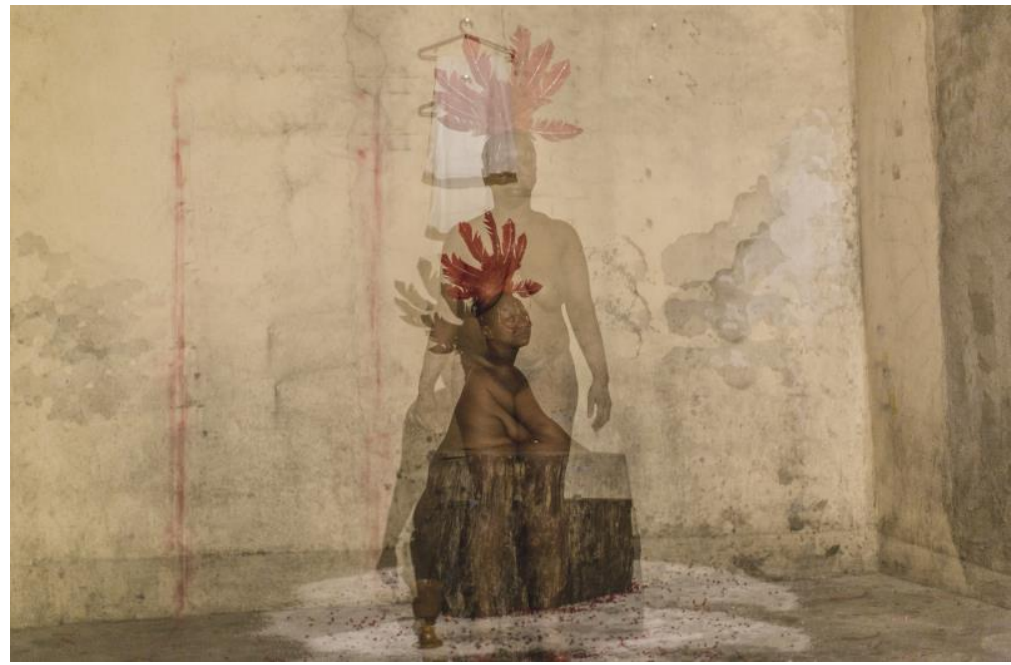

Photograph: Marcelo Paixão.

Mattiuzzi named these gatherings and collective arrangements, some of which happened during the 2016 Rio Olympic Games, "jogo das minorias" (minority games). And as I think of them, a few pressing questions come up: How should we read Mattiuzzi aesthetics of precariousness, mobility and displacement? What if we understand these random gatherings as a kind of black social life and as black study? Can we claim that this mode of social life proposes a disruption to modern society, that it is a sign of (a forced) letting go of the world as we know it? Is it a move toward a common life located in destitution and in refuge? Can we claim that Mattiuzzi's practice carries an aesthetic of the self who never assumed the figure of a subject?

The artist's fragmentary appearances were, at times, accessible through her posts on Facebook, Instagram and other media she deemed convenient to use. The limiting financial condition that kept her from producing and maintaining documentation of her work, Mattiuzzi embraces as an economy of 
control for accessing and distributing her images. One iconic work that emerges from this phase in the artist practice is Para ressurgir das próprias cinzas uma fênix deve primeiro queimar/In order to rise from its own ashes, a Phoenix first must burn (2016), a title possibly inspired on Octavia Butler's quote. The $1,10 \mathrm{~cm} \times 1,65 \mathrm{~cm}$ triptych marks a kind of end of the artist's personal world, after her apartment in Salvador (Bahia) was burned or, using her own words, after it was "queimado, incendiado, incinerado" [burned, set on fire, cremated]. Another important work from this phase is the film Experimentando o vermelho em dilúvio/ Experiencing (or Trying) The Red in Flood (2016). Created with a performative script, and part of a larger, process based project that entails residual pieces such as live actions and documenting photographs (Images 7, 8 and 9), the film depicts Mattiuzzi walking through downtown Rio de Janeiro, a relevant stage to the slave trade in colonial Brazil, moving in a fast pace, as if running away from something or someone, toward the monument to Zumbi dos Palmares-the fugitive enslaved man, strategist and warrior who led, for 17 years, N'Gola Djanga or Quilombo dos Palmares, one of the most important quilombo communities in the Americas. With her face and mouth covered with an object that resembles a slave iron mask-possibly a direct reference to a known image, by Jacques Arago, of a slave from Rio de Janeiro wearing the object in the beginning of the $19^{\text {th }}$ century-Mattiuzzi stands in front of Palmares monument. ${ }^{11}$ She then takes off, one by one, the pins that hold the mask to her face. The gesture of removing the pins gives way to a flow of blood, at times mixed with a stream of tears and saliva-these fluids of life. The videowork ends with Mattiuzzi completing the process of removing her "mask." Part of what the artist considers now a trilogy with Merci beaucoup Blanco! and $A$ dívida impagável (2018), Experimentando o vermelho em dilúvio

\footnotetext{
11 The image with a slave using the "iron mask" appears in USSlaveblog and is labeled as "Slave Mask:" Image Reference, NW0191 Source: Jacks Arago, Souvenirs d'un a veugle. Voyage autour du mond par M. J.Arago...IParis, 183940, vol 1, facing p.119 usslave.blogspot.com.br consulted in 12/26/2017.
} 
seems to, in a way, conceptually wrap up Mattiuzzi's wandering project.

Image 9: Michelle Mattiuzzi , Experimentando o vermelho em dilúvio (2016), processo 2, São Paulo - SP

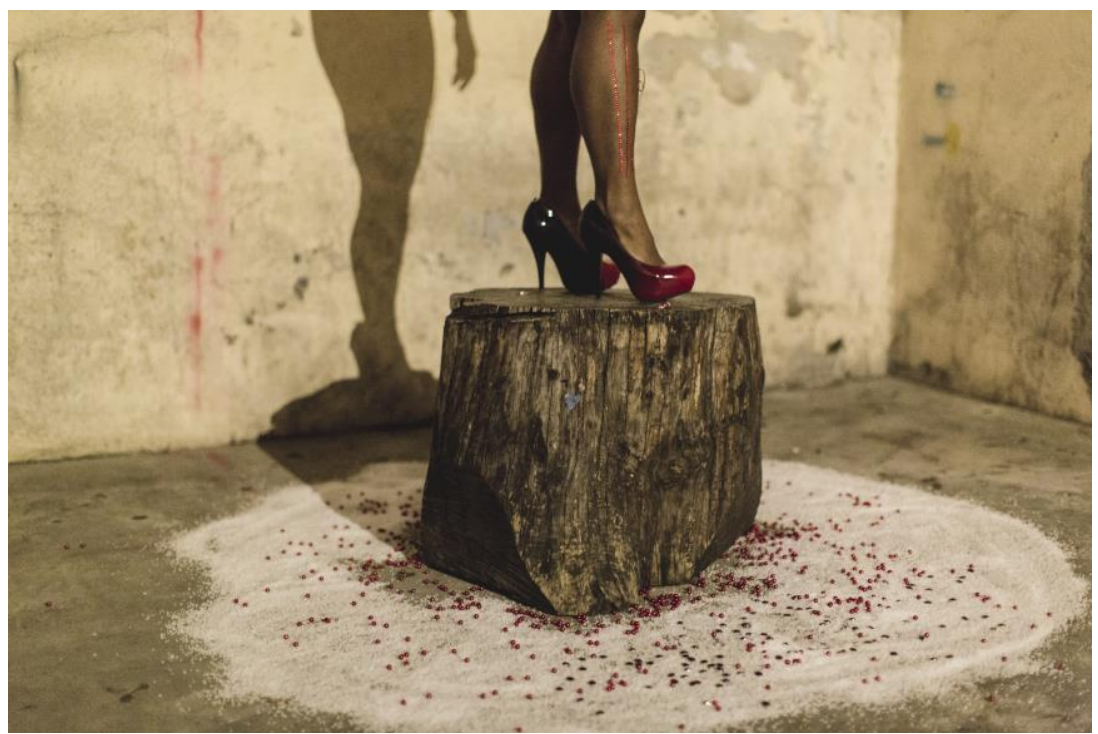

Foto: Marcelo Paixão

While offering a theorization of the term Ori (a Yoruba term which literal and immediate meaning is head) during a public conversation in November 2019, Brazilian poet Ricardo Aleixo states, "to speak of Ori is to speak of the top of the body, which are often related not to the head but to the feet." With that statement, Aleixo does a couple of interesting moves. One is to present AfroBrazilian philosophy (or rather, the, for the most part, Yoruba-centric side of AfroBrazilian philosophy) without much explanation and, therefore, as an intrinsic part of Brazilian popular culture and (not so popular) scholarly thinking. What I am after here, however, is the way Aleixo proposes an inversion in our common understanding of what constitute the top and the bottom of our material body, the way he places the feet as the center of 
the thinking process-and he does mention Capoeira and Samba, two practices that centers on the kinetic properties of the feet, as models for thinking processes. Aleixo's comment brings to mind an excerpt from Samba da minha terra [Samba of/from my land], a song by Dorival Caymi that goes:
quem não gosta de samba, bom sujeito não é, é ruim da cabeça ou doente do pé
those who don't like samba are not good people, they are sick in their mind or sick in their feet (Caymi, c 1940).

Theorizing on feet and on samba and their relationship to the "head" and to knowledge making, visual artist Juliana dos Santos comes up with the term sambiência. To Santos, sambiência conveys a "science" of knowing through samba that she describes as "ancestral knowledge that comes from the feet,..." (Santos in interview with Lopes, 2018). Thus, the relevance of the feet in serious and thoughtful reflection about knowledge is brought up once again.

In Wandering: Philosophical Performances of Radical and Sexual Freedom, North-American scholar Sarah Jane Cervenak presents the act of wandering as black people's philosophical response (or philosophical moving practice) to the
violently paradoxical crisis of unfreedom -where unfreedom meant, among other things, being ontologically codified as the nowhere, the detour, the backyard, and the movable and material sign of white diversion (Cervenak, 2014:2).

Moreover, Cervenak states that "wandering... offers new pathways for the enactment of black female philosophical desire" (Cervenak, 2014:9).

The converging (or rather entangled) point of these three propositions briefly presented above opens a window into an expanded view of Mattiuzzi's wandering practice: it invites us to 
seriously engage with the artist deambulations as both material moving energy that comes from the "top" of the body-the feetrelated center of thinking-, and as a practice of philosophical performance marked by complexity and radical in its possibilities.

\section{References}

ALEIXO, Ricardo. Michelle Mattiuzzi, 2019 [https://www.instagram.com/ricardoaleixoakavulgo/ - accessed in 11/20/2019].

BISPO, Alexandre Araujo and LOPES, Fabiana. Presenças: performance negra como corpo político (Presences: Black Performance as Body Politics). Harper's Bazaar Art Brasil, São Paulo, 2015, pp.106-112.

. Corpo, Festa e Dor, Ativismos, Estereótipos Raciais e História Social da Arte em Michelle Mattiuzzi. O Menelick 2o. Ato (n. 01, December 2013) pp.24-28.

CARNEIRO, Sueli. Gênero e raça na sociedade brasileria. In: Escritos de uma vida. Belo Horizonte, Letramento, 2018, pp.155.

CAYMI, Dorival. Samba da minha terra. Eu vou pr'a Maracangalha. Gravadora Odeon, 1957.

CERVENAK, Sarah Jane. Wandering: Philosophical Performances of Radical and Sexual Freedom. Durham and London, Duke University Press, 2014, pp.2.

FERREIRA, Bia. Negra tinta. [https://youtu.be/QiibNepUwhE. - accessed in 12/20/ 2019].

GONZALEZ, Lélia. Primavera para as rosas negras: Lélia Gonzalez em primeira pessoa. Editora Filhos da África, 2018, pp.124. [1982],

HARTMAN, Saidyia. Scenes of Subjection: Terror, Slavery and SelfMaking in Nineteenth-Century America. Oxford, Oxford University Press, 1999, pp.116-121.

HERNANDEZ, Tanya Katerí. Racial Subordination in Latin America. New York, Cambridge University Press, 2013, pp.47.

LEWIS, Gail, Questions of Presence. The Feminist Review Collective (117), 2017 pp.1-19 
[https://journals.sagepub.com/doi/10.1057/s41305-017-0088-1 accessed in 12/13/2019].

LOPES, Fabiana. Black Performance in Brazil: Hidden Stories and the Rough Vibrancy of Now. NKA Journal of Contemporary African Art. (44), Durham-NC, 2019, pp.64-76.

. Conversation with Juliana dos Santos, Ancestral Knowledge That Comes From the Feet. Contemprary And (C\&) América Latina (2018) [https://amlatina.contemporaryand.com/editorial/o-saber-ancestralque-vem-dos-pes-juliana-dos-santos/ - accessed in 12/20/2019].

MARTIN, Randy, Critical Moves: Dance Studies in Theory and Politics. Duke University: Durham \& London, 1998, pp.206.

MATTIUZZI, Michelle. Interview at Vasli Souza Gallery. Malmo, Sweden, 2013 [https://youtu.be/-IYnXBt8ZaE - accessed in 10/05/2018].

- No umbigo do Brasil experimento ABISMO (unpublished text, shared by the artists in 2016, pp.1).

. Migration Is Not For Everyone. In: PRATES, Fabia. Resistance Is Up To Us, Contemporary And Latin America, 2019.

MOTEN, Fred Moten. Consent Not To Be a Single Being: Black Blurr. Durham, Duke University Press, 2017.

REIS, Tassia. Preta D+. Próspera, 2019.

ROBINSON, Cedrid J. Black Marxism: The Making of The Black Radical Tradition. The University of North Carolina Press: Chapel Hill, 2000.

SPILLERS, Hortense. Mama's Baby, Papa's Maybe, an American Grammar Book. Diacritics, vol. 17, n. 2, Culture and Countermemory: The "American" Connection, Summer, 1987, pp.64-81.

WEHELIYE, Alexander G. Habeas Viscus, Racialicing Assemblages, Biopolitics And Black Feminist Theories of the Human. Durham, Duke University Press, 2014, pp.38. 